\section{Transformative learning in joint leadership}

\section{Transformative learning in joint leadership}

\author{
Lena Wilhelmson
}

National Institute for Working Life, Stockholm, Sweden

\begin{abstract}
Purpose - The aim of this paper is to show what the leaders themselves regard as the working ingredients in their mutual work situation that help to facilitate personal development.

Design/methodology/approach - In the paper data were collected through semi-structured interviews with 14 leaders at low and middle management levels in different lines of business within the private and public sector. The analysis of the learning processes draws on the theory of transformative learning.

Findings - The paper revealed that joint leadership, according to the leaders, could provide the leaders themselves with a basis of personal development and learning. This depends on common core values, a supportive relationship and common work processes as well as complementarity, joint sense making and critical reflection.

Research limitations/implications - The implies that joint leadership provides possibilities of transformative learning through examination of different points of view, through explicitly talking about habits of mind, and through stepwise changes of existing frames of reference. The results indicate that joint leadership offers the possibility of a deepened learning process in daily work in a communicative relationship where profound values and ways of acting are openly shared and critically-reflected upon. Joint leadership should however not be forced on to managers.

Originality/value - The paper provides insights into learning processes for leaders, based on the possibilities, which can be created through joint leadership.
\end{abstract}

Keywords Shared leadership, Self development, Learning processes

Paper type Technical paper

\section{Introduction}

A new form of leadership has been attracting attention in Sweden lately. All branches of employment have been found to present many forms of close co-operation between managers, including what is termed joint leadership (Döös et al., 2005). Managers practising joint leadership claim that it gives them strength and stamina in their everyday work (Döös et al., 2003; Döös and Wilhelmson, 2003). They also maintain that joint leadership impacts on their own personal development, through processes heavily related to the interaction within the leader pairs. The present paper sets out to show what the leaders themselves consider to be the working ingredients in their mutual work situation that help to facilitate personal development. The term joint leadership will be used to define situations where two persons in both formal and practical terms share work tasks, responsibility and authority, as well as sharing the same managerial position. The theory of transformative learning was chosen as a theoretical lens because of its explanatory value for processes leading to in-depth personal development.

\section{Previous research}

Empirically based studies of personal development and learning among managers/leaders in their day-to-day working lives have to some extent been

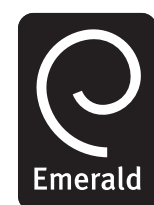

Journal of Workplace Learning Vol. 18 No. $7 / 8,2006$ pp. $495-507$

(C) Emerald Group Publishing Limited $1366-5626$ DOI $10.1108 / 13665620610693042$ 
JWL $18,7 / 8$

\section{6}

reported in the literature, e.g. in connection with development programmes of various kinds. Dixon (1993), for example, suggests that management development programmes should be designed to support situated learning in real work and in community rather than individually. Olusegun (2004) argues that role-playing as a pedagogy technique can enable leaders to see the differing roles and responsibilities of leaders. They can then develop critical skills and attitudes, learning to focus on themselves as leaders in relation to other people and to elaborate self-reflection.

Viittala (2005, p. 448) notes that: "managers' consciousness and interpretation of their development needs should be supported in organisations" because managers tend to view their own competence needs too narrowly and content-specifically, mainly regarding competencies limited to technical and business issues. In order to perceive their own learning and development needs, therefore, managers need to be made aware, for example of social and intrapersonal competencies. Tickle et al. (2005), similarly, maintain that epistemological beliefs among managers influence the extent to which they can act as facilitators of learning in the organisation. The authors argue that interventions targeting the development of mature beliefs are needed in order to support the development of transformational leadership, a leadership characterised by intellectual stimulation and individual consideration for and belief in subordinate learning and development.

The importance of core values is emphasised in literature focusing on so-called authentic leadership (Gardner et al., 2005; Lord and Hall, 2005; Shamir and Eilam, 2005). Self-awareness of one's values, that is, of conceptions guiding action and thinking, is crucial to managers' ability to develop authentic leadership (Gardner et al., 2005). To develop from novice to intermediate to expert skill levels as manager also means developing a value-based authentic leadership. Core values then become an integral part of the leader's identity. This demands formal training, deliberate practice and extensive experience according to Lord and Hall (2005). Shamir and Eilam (2005) argue, for example, that reflection, interpretation and revision of life-stories can contribute towards self-knowledge and authentic leadership.

Different forms of non-single leadership are rarely treated in the international literature. When they are, it is mostly at Chief Executive Officer (CEO)-level (Heenan and Bennis, 1999; Daft, 2001; O’Toole et al., 2002), when enterprises are being merged (Troiano, 1999), or as mentor and protégé relationships of co-leadership (Solomon et al., 1953). In the Swedish context the work process (Döös et al., 2003) and occurrence of joint leadership (5 percent of managers in Swedish working life work in joint leadership) and the occurrence of shared leadership (41 percent of Swedish managers) have been studied (Döös et al., 2005). A related phenomenon has been described as shared leadership in teams (Pearce and Conger, 2003), when leadership responsibility is distributed within a team. Studies of partnerships between firms (Kanter, 1988) do to some extent touch upon the need for close co-operation between executives as well as others in the organisations involved. Factors associated with partnership success include: commitment, co-ordination, interdependence and trust. Communication behaviour and conflict resolution techniques are also said to be important (Mohr and Spekman, 1994). Intra-organisational, cross-profession partnerships, are studied by Franz (2005), from a transformative learning perspective, about which more presently. 


\section{Transformative learning theory}

The theory of transformative learning (Mezirow, 1991, 2000) offers possibilities of analysing learning processes in communication and interaction. The transformative learning theory (TLT) deals with a deepened learning process based on critical reflection. Through TLT's main theoretical concepts the work processes of joint leadership can also be analyzed and understood as processes of learning. Habits of mind and points of view constitute the selective frame of reference through which perceptions are filtered (2000). A frame of reference consists of cultural paradigms and idiosyncrasy from personal history. Habits of mind and points of view are developed in tune with the social, historical and cultural currents in society. Learning within existing frames of reference means developing meaning structures that are taken for granted. Critical reflection is needed for a person to assess what is heard and seen, to be able to make judgements concerning statements made by others. But to free oneself from personal or cultural limitations in the world-view, one also needs to develop ability for critical self-reflection - to see through constraints that have become part of one's self-perception and obstacles for development. According to Mezirow (ibid), a disorienting dilemma creates a state of disequilibrium concerning assumptions earlier taken for granted, which is the trigger of perspective transformation.

Transformative learning, on a collective level (as between joint leaders), involves perspective change in a communicative context (Wilhelmson, 1998, 2002). Thus the individual focus of the transformative learning theory can be applied to a small group; individuals learn through the interaction between the members of the group. Perspectives in this context change through broadening, shifting and/or transcending. Broadening within one perspective means that no change of perspective occurs, statements are confirmed or ignored. This can be seen as an assimilative process. Shifting between perspectives means that different opinions meet. This creates a state of disequilibrium, which might open up for perspective change or alternatively get bogged down in debate. The transcending of perspectives creates a common and qualitatively new understanding. A collectively built new knowledge emerges that could not have been developed from one perspective only. This can be seen as an accommodative process, with people in a group adapting to the assessment of reason as they collectively build a new understanding. The transcending of perspectives is the engine of collective transformative learning.

Transformative learning is simultaneously social and individual. Scott (2003) highlights the social construction of transformation, which includes five processes: disequilibrium, internalisation, relationships, imagination and changes in consciousness. The change dynamic of disequilibrium, according to Scott, occurs in participative action at the same time as relationships become the containers for the internalisation of external experiences. Preece (2003) compares transformative leadership and transformative learning and concludes that processes associated with transformative learning also pertain to the transformative leader's developmental stages for change. Those leaders, according to Preece, could be challenged to develop a deeper understanding of the transformative learning process and its similarities to transformative leadership process of inspiring for change.

Franz (2005) found five common conditions that promote transformative learning in partnerships between county educator and campus faculty partners:
Transformative learning in joint leadership 
JWL $18,7 / 8$

498

(1) Partner facilitation through reflective discourse, using methods like teaching, questioning, exploring theory, playing devil's advocate, challenging assumptions, modelling, and providing honest feedback.

(2) Critical reflection through critical thinking about individual, work, and process assumptions, resulting in broader views of their work.

(3) Critical events as a foundation for change through providing disorienting dilemmas, leading the partners to reflect on the associated discomfort.

(4) Difference in personality, work styles and worldviews between partners, bridged by a common purpose.

(5) Independence with interdependence, retaining personal autonomy yet depending on each other to enhance work.

This characterisation of transformative partnerships is similar to the personal adult development described by Kegan (1982) as a spiral movement oscillating between independence and inclusion. Franz (2005, p. 265) concludes:

Joint leadership that facilitates reflective discourse around personal and shared assumptions promotes transformative learning. A deep developmental view of facilitation rather than a simple process approach results in deep change in one or both partners.

\section{Approach}

Data from an ongoing research program on joint leadership (Döös et al., 2003; Döös and Wilhelmson, 2003; Döös et al., 2005) have been used for an analysis of joint leaders' experience of working together. Seven leadership pairs, at low and middle management levels, were chosen for the special study accounted for in this paper. They were picked out because of their long (five years or more) and successful work together. The supposition was that those pairs have had an opportunity to develop a relationship and ways of interacting that were part of their successful management. Four of the pairs work within the private sector (nos. 1-4) and three within the public sector (nos. 5-7), altogether 11 women and three men, as shown in Table I. All except pair no. 2 were appointed as managers and responsible for finance and personnel. In the text they are all labelled "leaders", since this concept has a broader connotation than "manager", and the pairs will be referred to by their number in Table I.

The data consist of 13 semi-structured interviews with the 14 leaders, eight of them individual and five with both leaders at the same time, as is shown in Table I. All interviews were audio taped and transcribed. Since we discovered the phenomenon of joint leadership in a study including pair no 1, the first interviews with that pair were not focused on joint leadership as the following interviews were, but on organisational development.

The business activities of the seven pairs were documented as successful in different ways, economically as well as measuring customer and employee satisfaction. Some of them won prizes, e.g. as best manager $(3,5,6)$ or acquired high ranking in performance quality (1), the school of pair 5 was certificated by Investors in People. Some took on units or groups with a lot of problems and got them working $(1,5,6,7)$, one pair influenced their organisation to make joint leadership the main leadership form (7). The decision to work together was the leaders' own. They had noticed each 


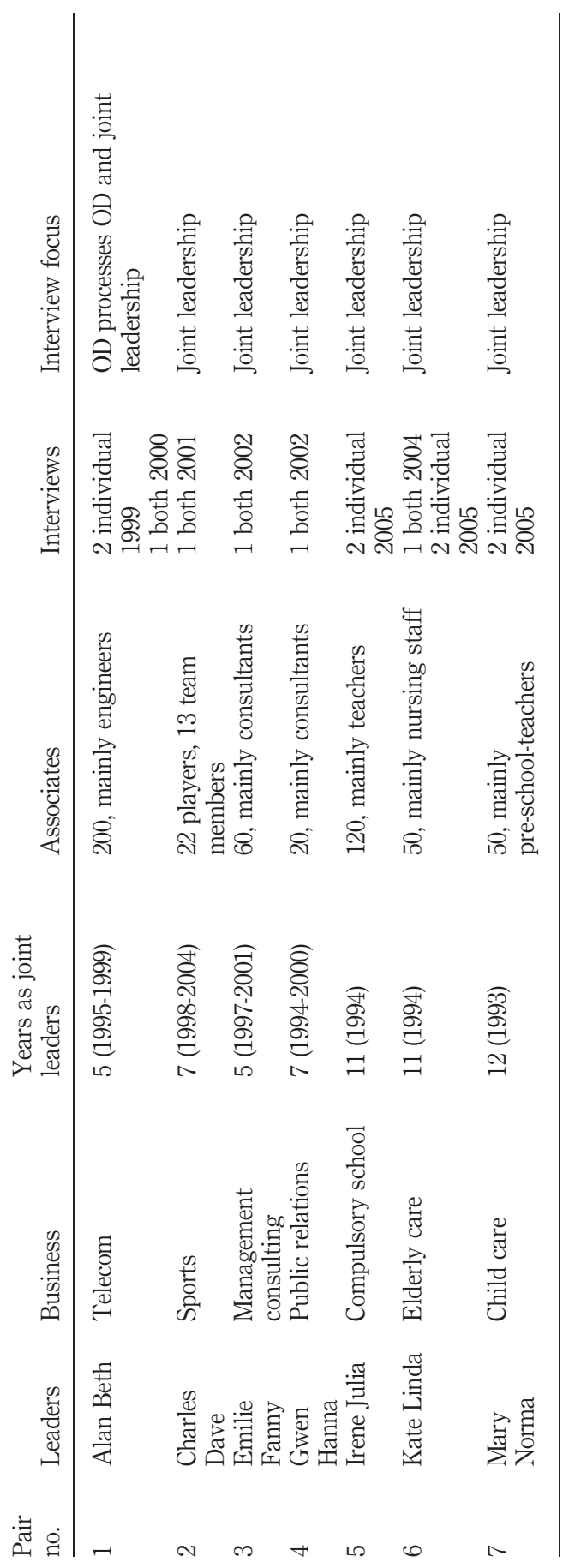

Transformative
learning in joint
leadership

499

Table I.

The leadership pairs and the interviews made 
JWL $18,7 / 8$

other at the workplace, at some distance, as competent persons and then decided to work together.

Data analysis identified aspects that the leaders themselves emphasised as important for the way they work together. A number of edited quotations are used as examples. The first names, as listed in Table I, have been invented.

\section{0}

\section{Findings}

The findings are discussed under a series of headings, some of which partially overlap. Firstly the importance is presented of common core values, something, which all leaders emphasise as an absolute prerequisite of joint leadership. Account is then given of the basis of joint leadership, comprising supportive relationship and common work processes. Complementarity and joint sense making, which are described next, rest on this foundation. These things together are the prerequisites of critical reflection and personal development.

\section{Common core values}

The joint leaders emphasised the necessity of having common values, deeply rooted in a humanistic outlook on persons, being non-prestigious, mutually trusting, loyal and generous towards one-another. This unity of core values made it possible to work towards common goals, the leaders stated:

We feel a great confidence in each other, one really feels that one can trust one-another, that we have the same core values (6).

The humanistic outlook was ever-present in thoughts and actions. As a consequence the leaders organised their units to work in collective collaborative forms, with distributed responsibilities and a developed communicative infrastructure for meetings and talk, for themselves and for their associates:

We have tried to build up an organisation that is founded upon exactly this commonality, the participation and responsibility, which also leads to improved learning, we think (7).

\section{A supportive relationship}

Frequent interaction formed a tightly knit relationship between the two leaders that made joint leadership a way of being together, as when they said things like:

“one of us sat us down” (4) or "our intuition”(1).

The joint leaders emphasised the importance of choosing the right partner. Companions are not interchangeable. It takes time to create a relationship - to trust and have confidence in one another, to develop common values and let go of prestige-mindedness, they claim. It is a process to develop as joint leaders, to build solidarity and to learn how to:

cover for each other when the wind blows (5).

In the interview Beth tells Alan how she appreciates his generosity and ability to listen:

And since I have a different view on things, it would never have been possible if you hadn't been so generous in giving up space and listening to this. It is very important to be generous, that there is room for confidence (1). 
Thus, the joint leaders described a supportive relationship with joint responsibility and authority, which they compared to that of a marriage. One of the pairs (4) even used a human resources consultant at one time to get to the bottom of their relationship: "Shall we go on together or not?"

The relationship gave the leaders strength to uphold developmental tasks and quality work and not get stuck in daily operative tasks. In relation to their organisation, to their own manager, to their colleagues and to their associates they could act with integrity, e.g. they could decide how to act in front of the associates and "what messages to send" (4). To be well reasoned and at the same time courageous made it possible for them to find their own path and the strength to argue for it. The strength was used to cope with difficulties, e.g. when taking over work teams with difficulties among the personnel, or units with economic difficulties, or simply units not working very well.

The leaders meant that they had to be observant of the risks of becoming too strong together and thereby closed without the ability to open up, first, towards the associates. It was therefore their express intention to spread responsibilities and authority further to their associates.

\section{Common work processes}

Continually the leaders prepared the everyday process of common work in fast and short cycles of co-operation. They describe how they worked out common planning systems, such as going over the coming week every Friday afternoon with the aid of notelets for the most important things to be done. Preparing things together, to achieve the same outlook, also created the force to act:

In practice, no matter what tasks lie ahead, we make a rough plan, then divide the work between us so that one of us works out a more detailed suggestion. Then we get together again. That is, we sort of go into and out of a kind of process activity the whole time (2).

The leaders had to handle problems, and they were not always in agreement from the beginning but discussed between themselves until they agreed on practical issues and on strategic plans. They saw themselves as each other's sounding boards. Problem solving and resolution of difficulties through ongoing communication seemed to be the tool for the joint leadership. Always having someone equally interested to talk to about everything was seen as an advantage. The joint leaders supported each other in difficulties and in handling crises. This support also included joy as a driving force in the daily work, they stated. Joint analysis of setbacks and shared joy in times of success made them learn from mistakes and gave energy to go on:

A joy that is shared is a joy made double somehow because when you are successful you always have someone to share it with and that is much more fun, to say that we did it together: Look, they are satisfied with us and we got this assignment! And then you have someone to toast with, that is not much fun to do on your own. I can think that this of winning on your own, that is really boring (4).

The leadership often meant hard work, hardships were part of the leader pairs' joint journey:

We met a lot of resistance. It had its price, it has been tough, but we've still wanted to see whether it would actually work. Working with group processes is really exciting (5). 
JWL $18,7 / 8$
Problems also occurred at times when, for different reasons, they didn't always have the strength to stand up for each other. One of the pairs (1) got problems when they merged with another unit and tried to manage as three leaders, for a short period of time. At different intervals the managerial work got out of balance in some of the pairs due to personal weaknesses, lack of experience or an imbalanced distribution of the work tasks. Otherwise difficulties could arise in relation to a superior manager or colleagues on the same managerial level, due to joint leadership contravening the established patterns of things. There were instances of other managers, who had had no personal experience of joint or shared leadership, thinking it was unclear and bad for the associates, or feeling themselves threatened by the strength shown by the joint leaders, some of the pairs maintain. Ordinary managers could also be made to seem losers compared with joint leaders who did not have to forsake their private lives in order to be managers.

\section{Complementarities and joint sense-making}

The joint leaders considered themselves complementary in capabilities and talents. They consciously handled their shortcomings and made use of their different personalities, in that way complementary capabilities also developed over time:

It was really stimulating to work with Beth, because I came to deal with softer aspects; how people work. And I have never seen anyone use their tentacles in the way she does, to catch what happens and how things feel. And how she manages it, we can talk about a production manager, why he takes the decisions he does. And she manages to bring out the essence of how he thinks when he does the things he do. Things I have never thought of before! (1).

The leaders said they noticed different aspects of things and took on different roles, which made the relationship both dynamic and energetic. They described themselves as different in ways that allowed time and space for reflection without slowing things down; while one of them is more thoughtful, careful and analytic the other is more daring, fast and unafraid or a "doer". Or, they describe it by saying that while one is more social and easygoing, the other comes out as harsher:

And then we are different. Fanny, she is straighter to the point: now we know what to do, let's do it, don't sit there and dawdle! And I am more thoughtful. But when we do it together, when we formulate our common path, we find a wider path, one that is less winding than mine and not as hectically straight as Fanny's, but has the good parts from both our sides. Then we always get further; the sum of our differences always equals more (3).

Thanks to mutual respect for each other's ways, personalities and knowledge, they could take advantage of their personal differences. The joint leaders claimed to both think and act together. They saw, heard and experienced each other in action. By jointly making sense of things they developed ability for common action. Mutual interests and responsibilities were reinforced by shared and thorough thinking, and through ongoing conversation and action together on an everyday basis. To think, talk, draw, make visible to each other, to continuously verbalise and visualise things makes them clearer, the leaders said. Thus, they felt comfort in the common sense-making process; their understanding became well grounded since it integrated different aspects and connected values to practice. To talk things through was a work that paid itself in a greater readiness to make fast decisions out of a mutual feeling for what needed to be done. 
Critical reflection and personal development

Mutual and critical reflection on problems and difficulties, as well as the formulation of new ideas, was essential for handling the shared tasks of management. Several of the leaders said they had outspokenly agreed to criticise each other's ideas:

We think alike most of the time since we stand on the same (value) ground. But we also disagree. And we can discuss that. And we can disagree in front of the group also, I think it is good that they see that we don't always agree (5).

In this way the joint leaders examined each other's way of working on a daily basis. But to question one-another also demanded mutual respect and the ability to listen to feedback and critique, they stated:

We have said that what's most important in working like this is to critically examine each others' points of view all the time. That way you get two fresh eyes on an idea. It is extremely important that you have a respect for one-another and dare be critical if there is a need for it (2).

Through critical reflection new approaches could be found, according to the leaders. An example of how pair 6 discussed their differences with regard to the associates can serve as an illustration:

Researcher: Do you have differences with regard to the personnel?

Kate: Yes, you can see people differently.

Linda: Exactly. That is rather important that you can do. I see things one way and feel that Kate doesn't see that, that we are far apart. To still be able to sit and talk about it and feel as if we can meet halfway. And that you are allowed to say: 'That is not what I feel, that is not how I see things.' I think it is rather important that you can do this. And not feel defeated, but that it is quite natural. You hear different things.

Kate: And I think that it is an asset, this that we see things differently, it has to be an asset in development possibilities. Because there wouldn't be any development if I was to sit on my own and think, because things are seldom black or white, but often in between, you can angle things differently, and look at things differently. I think that it is good to be able to see things differently.

Researcher: Do you think that you often have to compromise with your own view of things or is it rather that you move to another position and start to see things also from the other persons perspective?

Linda: I think that it is both. You have to make compromises with yourself, and feel that even the highway isn't all straight, it also has sidetracks. So you have to feel that you have to try and think of things from both aspects. But sometimes it is hard, definitely.

Kate: It is a process. That also happens sometimes within yourself, that you have to change your mind.

Linda: Yes, and it is good for you.

What these leaders point to, in other words, is critical reflection as a part of their own personal development. Another example is given by pair 5, about how they role-play when they have to handle difficult situations:

\section{Transformative learning in joint leadership}

503 
JWL $18,7 / 8$
We have some kind of game between us; we look through situations that might arise. I can provoke her so that she can try things out on me. If she has to sit in a tricky situation with someone in the staff and explain something, then I can be the staff and try to live the part. She starts the conversation the way she intends to do it. And then I answer her in a way that she has to react to. That way she has already met the worst resistance and comments by trying it out on me. We have some sort of role-play almost (5).

The joint leaders claimed that they contribute to each other's development through the common work process. Each of them became a more reflective leader, thus being two had also brought with it personal development. Their own learning was an everyday achievement through the ongoing processes of common sense making and critical reflection:

So I learned a lot during that period, and I suppose Beth did too. She's ready to test new ideas, and so have I been all the time - jumping at new things, being unafraid, wanting to learn (1).

All scenarios like this we have acted out the evening before, and I don't think I would be so inspired to do it if I were sole trainer. Because you force each other into this kind of thing. It's become such an in-service training for us, it's incredible (2).

We became strong, we became courageous, we became better reasoned, because we were two and could bandy ideas with each other (3).

And, to be able to grow, also in everyday work, in the moment. For this is what we get all the time when things work well, by sharing things, that even if you have just written something, it is sort of up for discussion immediately (4).

And it is a weakness that I sometimes avoid things that make me less popular, I think that I have improved in this. I have learnt a lot from Julia. You can be well liked even if you don't say yes all the time or aren't always positive. You can still be respected (5).

You can develop each other, I believe. I have a great need of discussing and talking about things, getting together. I think it's developmental, I think otherwise you stand still a lot more. We've moved the operation forward and it certainly hasn't stood still, which I think it would have done a lot more if we ourselves had just sat about (6).

Sensitive and open, yes I think it has changed me. Yes, I think I have changed for the better actually. I can see that this of being both boss and leader has changed me. When I worked alone, I was more of a boss all the time (7).

To be forced to continuously handle change also demanded continually changed understanding, the leaders stated. Since they had the work tasks in common they developed this understanding in common. They talked and changed their way of thinking and said they did this without feeling threatened.

\section{Concluding discussion}

The special working conditions that joint leadership gives rise to - having work tasks, authority and responsibility in common - seem to create a particular breeding ground for leaders to develop in their work. One interpretation is that joint work tasks almost forces the leaders to develop together since they were frequently and often deliberately subjected to each other's opinions. When they discuss how to handle the many problems they have to face, they develop their points of view (Mezirow, 2000), and 
when they encounter problems that pose an ethical or moral dilemma they force each other deeper into thinking about core values with epistemological and ontological dimensions, maybe challenging each other to make epistemological shifts (Kegan, 2000).

In facing challenges and problems the joint leaders place themselves in a situation beneficial for transformative learning, i.e. that of disorienting dilemmas (Mezirow, 2000). Since they have close access to each other they gain the strength to deal with doubts and insecurity and develop creative solutions. They learn how to get through the various phases of the transformative learning process, e.g. that hard phases of critical assessment of assumptions will result in common and better ability to lead. In this way, joint leadership provides potential for transformative learning through stepwise changes of existing frames of reference (ibid) in an accumulative way. The prerequisites of "reflective discourse around personal and shared assumptions" (Franz, 2005, p. 265) which promotes transformative learning can be seen among these joint leaders in a similar way as among Franz's partners. Through interaction the joint leaders shifted and transcended (Wilhelmson, 2002) each other's perspectives. They also made use of other people's deviant perspectives, mainly those of their associates.

Transformative learning might be understood as a deepened learning process in daily work through a communicative relationship, built upon profound values. Thus, through collective transformative learning the joint leaders developed a new and mutual third way of understanding, possible for both of them to act on the basis of. Twosome-ness means that the leaders can reflect on their joint leadership, acquiring a sort of common life-story (Shamir and Eilam, 2005), which they can use for developing their epistemological beliefs (Tickle et al., 2005) and core values. In this way they develop a value-based authentic leadership (Gardner et al., 2005; Lord and Hall, 2005) with commitment, co-ordination and trust (Mohr and Spekman, 1994) in which they are both independent and interdependent (Franz, 2005) of and on each other.

To conclude, the results indicate that joint leadership, when working well, offers the possibility of a deepened learning process in daily work in a communicative, competence-bearing relationship (Döös, 2004) where core values and ways of acting are openly shared and critically reflected upon. For transformative learning to occur in joint leadership, safety and trust, together with openness, and a habit of questioning and critically reflecting on things, seem to be important. Having equal power, and complementary competencies and interests, also seems important. Dialogue within management is something solitary leaders never get access to. But, if leaders don't choose each other, if the organisation decides which people are to lead together, this could maybe obstruct the development of mutual trust and core values in joint leadership. An implication then of the study, for organisations, is to support joint leadership as it evolves in everyday practice but not to force it on managers against their own will.

The leaders in this study came from different lines of business, and yet considerable similarities emerge between their descriptions of how they work together, and how they assess the values of joint leadership. No differences arising from organisational structures or activities, or gender differences, could be seen with regard to these data, due possibly to the selection of a small number of successful pairs. A broader selection of managers might give other results when it comes to learning processes for the leaders themselves.

\section{Transformative learning in joint leadership}

505 
JWL $18,7 / 8$

\section{References}

Daft, R. (2001), Organization Theory and Design, 7th ed., South-Western, Cincinnati, OH.

Dixon, N. (1993), "Developing managers for the learning organization", Human Resource Management Review, Vol. 3 No. 3, pp. 243-54.

Döös, M. (2004), "Arbetsplatsens relationik - om vardagens lärande och kompetens i relationer (Relational mechanisms in the workplace - everyday learning and competence relations)", Arbetsmarknad and Arbetsliv, Vol. 10 No. 2, pp. 77-93.

Döös, M. and Wilhelmson, L. (2003), "Delat ledarskap - en trend i vardande? (Shared leadership a coming trend?)", in von Otter, C. (Ed.), Ute och inne $i$ svenskt arbetsliv, Arbetslivsinstitutet, Stockholm.

Döös, M., Wilhelmson, L. and Hemborg, ^̊. (2003), "Delat ledarskap som möjlighet” (Shared leadership as a possibility)”, in Wilhelmson, L. (Ed.), Förnyelse på svenska arbetsplatser, Arbetslivsinstitutet, Stockholm.

Döös, M., Hanson, M., Backström, T., Wilhelmson, L. and Hemborg, Å. (2005), Delat ledarskap i svenskt arbetsliv - kartläggning av förekomst och chefers inställning (Shared leadership in Swedish working life - an overview of its occurrence and managers' attitudes to it), Arbetslivsinstitutet, Stockholm.

Franz, N. (2005), "Transformative learning in intraorganization partnerships", Journal of Transformative Education, Vol. 3 No. 3, pp. 254-70.

Gardner, W., Avolio, B., Luthans, F., May, D. and Walumbwa, F. (2005), "Can you see the real me? A self-based model of authentic leader and follower development", The Leadership Quarterly, Vol. 16 No. 3, pp. 343-72.

Heenan, D. and Bennis, W. (1999), Co-Leaders: The Power of Great Partnerships, Wiley, New York, NY.

Kanter, R. (1988), "The new alliances: how strategic partnerships are reshaping American business", in Sawyer, H. (Ed.), Business in a Contemporary World, University Press of America, New York, NY.

Kegan, R. (1982), The Evolving Self: Problem and Process in Human Development, Harvard University Press, Cambridge, MA.

Kegan, R. (2000), "What 'form' transforms? A constructive-developmental approach to transformative learning", in Mezirow, J. (Ed.), Learning as Transformation. Critical Perspectives on a Theory in Progress, Jossey-Bass, San Francisco, CA.

Lord, R. and Hall, R. (2005), "Identity, deep structure and the development of leadership skill", The Leadership Quarterly, Vol. 16 No. 4, pp. 591-615.

Mezirow, J. (1991), Transformative Dimensions of Adult Learning, Jossey-Bass Publishers, San Francisco, CA.

Mezirow, J. (2000), "Learning to think like an adult. Core concepts of transformation theory", in Mezirow, J. (Ed.), Learning as Transformation. Critical Perspectives on a Theory in Progress, Jossey-Bass, San Francisco, CA.

Mohr, J. and Spekman, R. (1994), "Characteristics of partnership success: partnership attributes, communication behavior, and conflict resolution techniques", Strategic Management Journal, Vol. 15 No. 2, pp. 135-52.

Olusegun, A. (2004), "Efficacy of role-playing pedagogy in training leaders: some reflections", Journal of Management Development, Vol. 23 No. 4, pp. 355-71.

O’Toole, J., Galbraith, J. and Lawler, E. (2002), "When two (or more) heads are better than one: the promise and pitfalls of shared leadership", California Management Review, Vol. 44 No. 4, pp. 65-83. 
Pearce, C. and Conger, J. (2003), Shared Leadership. Reframing the Hows and Whys of Leadership, Sage Publications, Thousand Oaks, CA.

Preece, J. (2003), "Education for transformative leadership in Southern Africa”, Journal of Transformative Education, Vol. 1 No. 3, pp. 245-63.

Scott, S. (2003), "The social construction of transformation", Journal of Transformative Education, Vol. 1 No. 3, pp. 264-84.

Shamir, B. and Eilam, G. (2005), "What's your story? A life-stories approach to authentic leadership development”, The Leadership Quarterly, Vol. 16 No. 3, pp. 395-417.

Solomon, A., Loeffer, F. and Frank, G. (1953), "An analysis of co-therapist interaction in group psychotherapy", International Journal of Group Psychotherapy, Vol. 3, pp. 171-80.

Tickle, E., Brownlee, J. and Nailon, D. (2005), "Personal epistemological beliefs and transformational leadership behaviours", Journal of Management Development, Vol. 24 No. 8, pp. 706-19.

Troiano, P. (1999), "Sharing the throne", Management Review, Vol. 88 No. 2, pp. 39-43.

Viittala, R. (2005), "Perceived development needs of managers compared to an integrated management competency model”, Journal of Workplace Learning, Vol. 17 No. 7, pp. 436-51.

Wilhelmson, L. (1998), Lärande dialog. Samtalsmönster, perspektivförändring och lärande $i$ gruppsamtal (Learning Dialogue. Discourse patterns, perspective change and learning in small group conversation), Arbetslivsinstitutet, Solna.

Wilhelmson, L. (2002), "On the theory of transformative learning", in Bron, A. and Schemmann, M. (Eds), Social Science Theories in Adult Education Research, LIT Verlag, Münster.

\section{Corresponding author}

Lena Wilhelmson can be contacted at: lena.wilhelmson@arbetslivsinstitutet.se

\section{Transformative learning in joint leadership}

507

To purchase reprints of this article please e-mail: reprints@emeraldinsight.com Or visit our web site for further details: www.emeraldinsight.com/reprints 